\title{
Video Games as a Media for Tourism Experience
}

\author{
Yang Junko, Chia-Hsiang Hsu ${ }^{(\bowtie)}$, and Tsong-Zen Liu \\ National Kaohsiung University of Hospitality and Tourism, \\ Kaohsiung City, Taiwan \\ \{jacqueshsu, itzen\}@staff.nkuht.edu.tw
}

\begin{abstract}
Virtual reality technology in recent year has been a hot topic in tourism and hospitality field, both for research and practical purposes. Virtual technology has some limitation, such as costs and time, which can be addressed by a different form of virtual technology, which is video games. The purpose of this study is to analyze the effects of mental imagery, sense of presence and addition of storytelling towards tourism experience by using video games as a medium. Previous studies have analyzed effects of mental imagery and presence towards the tourism experience, but there is lack of research in using storytelling or narratives to add to the tourism experience. Storytelling has been studied in marketing field, and has been found to be a great marketing tool, because people love to hear stories. Video games can be a better tool for delivering storytelling, while providing solid mental imagery and a sense of presence to the location. The methodology proposed for this study is a quantitative approach, using survey questionnaire as a tool. Two sampling method is proposed. The first is to use players of location-based games as the population, and randomly take the sample. The second method is to uses tourists or potential tourists of a destination, have the respondents try out the game, and answer the questionnaire. The proposed research could provide the importance of storytelling to be added for virtual reality and video games usage in tourism and hospitality field.
\end{abstract}

Keywords: Video games $\cdot$ Tourism experience $\cdot$ Storytelling

\section{Introduction}

Virtual reality technology has been growing in recent years, and brought in new frontier for destination marketers to interact with tourists. With the ongoing COVID-19 pandemic, virtual reality technologies are considered as an alternative to traditional travel, reduce risk of diseases and foreign diseases from spreading, hence increasing its sustainability in the long-term (Schiopu et al. 2021). Virtual reality technologies also showed its usefulness in as a way to provide information (Huang et al. 2016), as a tool or method for research (Fox et al. 2009), substitute for traditional tourism (Guttentag 2010; Schiopu et al. 2021), entertainment, planning, and education purpose (Guttentag 2010).

Despite of the various uses of virtual reality technology, the technology itself has a few limitations that prohibits its widespread adaptation. The awareness of the technology is still low within the general public, the limited availability and high cost of the 
technology, the time commitment needed for learning to use the technology, and the willingness of people to substitute "real" experience with virtual experiences are obstacles faced by virtual reality technology application in tourism field (Yung and Khoo-Lattimore 2019). The challenges of virtual reality technology can be answered by another alternative technology, which is video games. Video games has 2.7 billion users worldwide in 2020 (Warman et al. 2019), which means people are aware of the technology. Video games is available everywhere, whether its in mobile phones, tablets, computer, or specialized console for gaming. As long as the game is not difficult, users are willing to continue learning and playing video games (Orvis et al. 2008).

Previous research has shown that interaction and information provided in a virtual environment can lead to people feeling as if they are present in the environment, bringing an unique tourism experience compared to other media, such as media or 360 degree picture (Bogicevic et al. 2019). There is little research regarding about this by using video games as a media. Previous research also did not include how storytelling can affect tourism experience in a virtual environment, although previous research shows that storytelling helps in making tourism experience more memorable (Tung and Ritchie 2011). Thus, the purpose of this research is to analyze the effect of mental imagery, sense of presence, and storytelling towards tourism experience with video games as a medium.

\section{Literature Review}

\subsection{Mental Imagery}

Mental imagery is the act of visioning an image without a sensory stimuli (Bogicevic et al. 2019; Kosslyn et al. 2006). The purpose of a mental imagery is to identify properties of an image, and recall related information from memory, and runs a parallel comparison of perception and imagery (Kosslyn et al. 2006). Mental imagery is important for tourism destination because it affects tourists' expected experience before arriving in a destination. Virtual environment in virtual reality or video games provide images, and moving images which requires cognitive function of the brain to understand the environment and helps in shaping a mental image of the environment (Bogicevic et al. 2019). Previous study by Bogicevic et al. (2019) has found that mental imagery influences the sense of presence felt by the user using virtual reality. This research proposes the following hypothesis with video games as a medium.

H1: Mental imagery has a significant effect towards sense of presence,

\subsection{Telepresence}

Telepresence is the feeling of being present within a remote or virtual site (Draper et al. 1998). In this case, the remote site is a virtual environment created by video games or virtual reality. The experience is felt by the user where they are displaced by their own perception into a simulated one (Draper et al. 1998; Steuer 1992). To achieve this effect, different sensory cues (e.g. visual, audio, etc.) from the virtual environment can 
be use to trigger the response. Previous study by Bogicevic et al. (2019) found that sense of presence enhance tourism experience when using virtual reality technology. This research proposes the following hypothesis based on previous study, but uses video games as a medium.

H2: Telepresence or sense of presence has a significant effect on tourism experience.

\subsection{Storytelling}

Storytelling refers to the act of sharing traditions, norms, experience, and knowledge between listeners and speakers through words and action in a narrative format in order to make it more comprehensible, meaningful, and memorable (Kim et al. 2020). Storytelling is one of the earliest forms of communication and we, as humans, are instinctively to have our thoughts and memories arranged in a narrative format (Ferreira et al. 2014). Hence, storytelling has become a trend in the experience industry as businesses started to built themselves from a story (Gravili et al. 2017). Storytelling from a destination helps visitors consume an experience, and incites emotions, and effect their sense of belonging and identification of the place (Bassano et al. 2019). Previous study by Yang \& Kang (2021) found that storytelling can positively affect the experience depending on the quality of the message (story) in invoking emotion and memory of the listeners, and how customer can relate their own experience with the story. Video games can provide different stories of characters and locations; hence the research proposes the following hypothesis:

H3: Storytelling has a significant effect on tourism experience.

\subsection{Experience Economy Theory}

This theory that is proposed by Pine and Gilmore (1998) explained that experience can be divided into 4 different realms. Previous research by Jung et al. shows that in a virtual environment, the users actively participate and are immersed with the experience. Due to some similarities and differences between video games and virtual environment, video games may give different kind of experience.

Experience felt by the tourist is vital because tourism experience can lead to higher attachment towards the destination by the tourists, and increased intention and retention to stay at the destination (Vada et al. 2019). Integral part of tourism experience is direct interaction (Bogicevic et al. 2019) and co-creation. Co-creation is seen as away to create unique and memorable experiences for visitors (Sugathan and Ranjan 2019). Video games or virtual environment can provide higher interactivity and engagement with its users in comparison to other traditional media, such as videos or printed media. Hence, the following research identifies from previous study how tourism experience can affect visitors' intention to travel.

H4: Tourism experience has a significant effect on intention to travel. 


\section{Proposed Methodology}

The proposed methodology for this study is a quantitative study. Quantitative study approach tests objective theories by investigating connections between variables (Creswell 2014). To select the sample, this research proposes find people who have played video games that are based on physical locations recently, such as Assassin's Creed franchise. Survey with items based on Bogicevic et al. (2019) and Yang and Kang (2021) will be given out online through communities of users who played the game before. Sites chosen will be Reddit and Facebook.

\section{Potential Implications}

The potential implications of this paper would be expanding the telepresence theory towards video games context. The finding could also highlight the importance of storytelling towards tourism experience. For practical implications, the findings can push practitioners to see video games an alternative tool to promote destination, and as an alternative for traditional tourism. With the ongoing pandemic, video games can be an alternative and a tool to promote and incite people to travel when the lockdown ends.

\section{References}

Bassano C, Barile S, Piciocchi P, Spohrer JC, Iandolo F, Fisk R (2019) Storytelling about places: tourism marketing in the digital age. Cities, 87:10-20. https://doi.org/10.1016/j.cities.2018. 12.025

Bogicevic V, Seo S, Kandampully JA, Liu SQ, Rudd NA (2019) Virtual reality presence as a preamble of tourism experience: the role of mental imagery. Tour Manage 74(February):5564. https://doi.org/10.1016/j.tourman.2019.02.009

Creswell JW (2014) Research Design Qualitative, Quantitative, and Mixed Method Approaches 4th Edition

Ferreira S, Pimenta Alves A, Quico C (2014) Location based transmedia storytelling: enhancing the tourism experience. In ENTER $2014 \mathrm{PhD}$ Workshop. http://www.ifitt.org/wp-content/ uploads/2014/05/eProceedings_ENTER2014_PhDWS-Jan17201411.pdf\#page=7

Fox J, Arena D, Bailenson JN (2009) Virtual Reality: A Survival Guide for the Social Scientist. J Media Psychol 21(3):95-113. https://doi.org/10.1027/1864-1105.21.3.95

Gravili S, Rosato P, Iazzi A (2017) Managing DMOs through storytelling: a model proposal for network and value co-creation in tourism. Int Bus Res 10(7):8. https://doi.org/10.5539/ibr. v10n7p8

Guttentag DA (2010) Virtual reality: applications and implications for tourism. Tour Manage 31 (5):637-651. https://doi.org/10.1016/j.tourman.2009.07.003

Huang YC, Backman KF, Backman SJ, Chang LL (2016) Exploring the implications of virtual reality technology in tourism marketing: an integrated research framework. Int J Tour Res 18:116-128. https://doi.org/10.1002/jtr.2038Exploring

Draper JV, Kaber DB, Usher JM (1998) Telepresence. Hum Factors 40(3):354-375. https://doi. org/10.1518/001872098779591386 
Inversini A, Schegg R (eds) (2016) Information and Communication Technologies in Tourism 2016. Springer, Cham. https://doi.org/10.1007/978-3-319-28231-2

Kim SH, Song MK, Shim C (2020) Storytelling by medical tourism agents and its effect on trust and behavioral intention. J Travel Tour Mark 37(6):679-694. https://doi.org/10.1080/ 10548408.2020.1795046

Kosslyn SM, Thompson WL, Ganis G (2006) Mental imagery. in the case for mental imagery, pp 267-294

Orvis KA, Horn DB, Belanich J (2008) The roles of task difficulty and prior videogame experience on performance and motivation in instructional videogames. Comput Hum Behav 24(5):2415-2433. https://doi.org/10.1016/j.chb.2008.02.016

Pine J, Gilmore JH (1998) Welcome to the experience economy. Harv Bus Rev 76(4):97-105. https://doi.org/10.1007/bf03036337

Schiopu AF, Hornoiu RI, Padurean MA, Nica AM (2021) Virus tinged? Exploring the facets of virtual reality use in tourism as a result of the COVID-19 pandemic. Telematics Inform 60:101575. https://doi.org/10.1016/j.tele.2021.101575

Steuer J (1992) Defining virtual reality: dimensions determining telepresence 42(4)

Sugathan P, Ranjan KR (2019) Co-creating the tourism experience. J Bus Res 100:207-217. https://doi.org/10.1016/j.jbusres.2019.03.032

Tung VWS, Ritchie JRB (2011) Exploring the essence of memorable tourism experiences. Ann Tour Res 38(4):1367-1386. https://doi.org/10.1016/j.annals.2011.03.009

Vada S, Prentice C, Hsiao A (2019) The influence of tourism experience and well-being on place attachment. J Retail Consum Serv 47:322-330. https://doi.org/10.1016/j.jretconser.2018.12. 007

Warman P, Wijman T, Meehan O, De Heij B (2019) Global games market report. https:// resources.newzoo.com/hubfs/2019_Free_Global_Game_Market_Report.pdf?utm_campaign= GamesMarketReport\&utm_medium=email\&_hsmi=76474808\&_hsenc=p2ANqtz-_3juWexkY-VssdjZIgpriNUZG7_-m1zBf0BoraW83z85FE_ spQC2XaweVzbTHGDRZ2L6XjW_KAYaqZoUw9AiL8PHE6r2jCtd15v

Yang KCC, Kang Y (2021) Predicting the relationships between narrative transportation, consumer brand experience, love and loyalty in video storytelling advertising. Journal of Creative Communications 16(1):7-26. https://doi.org/10.1177/0973258620984262

Yung R, Khoo-Lattimore C (2019) New realities: a systematic literature review on virtual reality and augmented reality in tourism research. Curr Issue Tour 22(17):2056-2081. https://doi. org/10.1080/13683500.2017.1417359

Open Access This chapter is licensed under the terms of the Creative Commons Attribution 4.0 International License (http://creativecommons.org/licenses/by/4.0/), which permits use, sharing, adaptation, distribution and reproduction in any medium or format, as long as you give appropriate credit to the original author(s) and the source, provide a link to the Creative Commons license and indicate if changes were made.

The images or other third party material in this chapter are included in the chapter's Creative Commons license, unless indicated otherwise in a credit line to the material. If material is not included in the chapter's Creative Commons license and your intended use is not permitted by statutory regulation or exceeds the permitted use, you will need to obtain permission directly from the copyright holder.

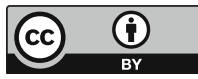

